\title{
Puerta Castillo. Una entrada emblemática para la ciudad de León
}

\author{
Emilio Morais Vallejo \\ Universidad de León
}

\begin{abstract}
RESUMEN. Durante el reinado de Fernando VI se construyó una puerta monumental en la muralla de la ciudad de León. Entre sus objetivos destacan el embellecimiento de la ciudad, la regularización del trazado urbano o el cierre del recinto amurallado. No obstante, prevalece la intención ideológica, utilizando de forma interesada los símbolos históricos para conseguir la característica persuasión del barroco.

Palabras clave: Arquitectura barroca, siglo XVIII, puerta de ciudad, murallas, León.

ABSTRACT. During the reign of Fernando VI a monumental gate was built in the wall of the town of León. This was done for several purposes: to control the urban layout, to allow for the closing of the walls and for the overall aesthetic improvement of the town. Nevertheless, the ideological intention prevails in the use of historic symbols in an interested fashion to obtain the characteristic persuasion of the baroque.

Key words: Baroque architecture, 18th century, town, gate, walls, León
\end{abstract}

\section{HISTORIA DE PUERTA CASTILLO}

El origen de la ciudad de León se remonta al último cuarto del siglo I, cuando la Legio VII Gémina ${ }^{1}$, creada por el emperador romano Galba, estableció su campamento en el interfluvio de los ríos Bernesga y Torío $^{2}$. Su asentamiento era un hito im-

\footnotetext{
${ }^{1}$ Sobre la fundación de la ciudad véase A. GARCÍA BELLIDO, Nueve estudios sobre la Legio VII Gemina y su campamento en León, León, 1968.

${ }^{2}$ La arqueología está demostrando en la actualidad que en el mismo lugar estuvo establecida anteriormente la Legio VI Victrix, pero su asentamiento fue temporal, mientras que el de la Legio VII tuvo condición de estabilidad y pronto se empezaron a construir estructuras sólidas con intención de perpetuidad. Véase, V. GARCíA MARCOS Y J. VIDAL ENCINAS, "Asturi-
}

portante de la calzada que iba desde Caesar Augusta (Zaragoza) hasta Asturica Augusta (Astorga), y se situaba en un lugar estratégico de comunicación entre la meseta $\mathrm{y}$ Galicia por un lado, y Asturias por otro, además de controlar las explotaciones auríferas cercanas.

Los romanos levantaron el campamento siguiendo el esquema tradicional para este tipo de fuerza militar. Una poderosa muralla defensiva dibujaba un rectángulo de esquinas ligeramente redondeadas con unas dimensiones aproximadas de 570 por 350 metros (unas 20 hectáreas de super-

ca Augusta y Castra Legionis VII Geminae en la Asturia Cismontana", en Astures, Oviedo, 1995, pp.113-127. 
ficie). Dos vías mayores, la cardo y la decumana, se cruzaban perpendicularmente $\mathrm{y}$ desembocaban en las cuatro puertas que daban acceso al interior del recinto. La primitiva empalizada de madera pronto fue sustituida por un muro de piedra, con un grosor de 1,80 metros ${ }^{3}$. Durante la época bajoimperial se adosó a este muro otro, el que en la actualidad está a la vista, que superaba los cinco metros de anchura y los ocho de altura, reforzado con torres de planta semicircular peraltada ${ }^{4}$. El paso de los siglos ha ido alterando su fisonomía con destrucciones, arreglos, reformas y adiciones, hasta conformar su apariencia actual ${ }^{5}$.

Las cuatro puertas romanas originales, según las crónicas antiguas recubiertas de mármoles y adornadas con inscripciones en las que se honraba a los primeros pobla-

\footnotetext{
${ }^{3}$ En la actualidad hay muy pocos vestigios de esta primitiva muralla, siendo los más interesantes los que se encuentran al lado de la torre de la colegiata de San Isidoro.

${ }^{4}$ La historiografía más antigua consideraba los muros actuales de la Edad Media, levantados tras las destrucciones realizadas por los musulmanes. Esta teoría parte de M. RISCO, Historia de la Ciudad y Corte de León y de sus Reyes, Madrid, 1792, seguida por algunos historiadores posteriores. Hoy en día se cree que fueron levantados en los siglos III y IV. El primero que defendió esta teoría fue I. A. RICHMOND, "Five townwalls in Hispania Citerior", The Journal of Roman Studies, XXI, Londres, 1931, pp. 86-100. Más tarde es reafirmada por otros autores, por ejemplo: A. BALIL ILLANA, "La defensa de Hispania en el Bajo Imperio", Zephyrus, XI, 1960, pp 179-197; C. FERNÁNDEZ OCHOA, y A. MORILlO CERDÁN, "Fortificaciones urbanas de época bajoimperial en Hispania. Una aproximación crítica", PAUAM, no 18-19, 1991; E. CAMPOMANES AlvAREDO, "Nuevas perspectivas sobre el recinto amurallado romano de León", Congreso Internacional Los orígenes de la ciudad en el noroeste hispánico, t. II, Lugo, 1996, pp. 1057-1076.

${ }^{5}$ Las murallas de León, tanto la primitiva romana como la posterior cerca medieval que amplió el espacio de la ciudad, fueron declaradas Monumento Histórico el 3 de junio de 1931, AA VV, Arquitectura monumental en la provincia de León, León, 1993, pp. 50-53; J. RIVERA BLANCO, Catálogo monumental de Castilla y León, Salamanca, 1995, pp. 327-328.
}

dores $^{6}$, estaban orientadas a cada uno de los puntos cardinales. Al este se abría la porta principalis sinistra, denominada Puerta Obispo desde la Edad Media; hacia el oeste la porta principalis dextra, después denominada Cauriense; al sur la puerta praetoria, que pasó a denominarse en el medievo Arco de Rey. Por último, mirando al norte se ubicaba la puerta decumana, más tarde conocida como Puerta Castillo o Puerta del Conde $^{7}$, porque a su lado estaba el Castillo de León, donde tenía su sede el conde encargado de la defensa de la ciudad ${ }^{8}$.

Las entradas seguramente estaban defendidas, como era habitual en los campamentos romanos estables, por un sistema de torres flanqueando los vanos de acceso. De la única que quedan vestigios originales es de la principalis sinistra, que unas recientes excavaciones han permitido comprobar en parte su estructura. Tenía dos vanos separados por una espina, situándose en sus extremos sendas torres de planta cuadrada. Desconocemos la conformación de las demás porque fueron desapareciendo a lo largo de la historia sin dejar memoria, pero es muy probable que tuvieran una morfología similar.

La puerta norte, motivo de nuestro estudio, a la importancia militar que tenía para los romanos como ingreso al interior del campamento, y añadía la circunstancia de que hasta allí llegaba un acueducto exterior decisivo para abastecer de agua a la legión ${ }^{9}$, que después se distribuía en distin-

\footnotetext{
-

${ }^{6}$ M. RisCO, op. cit., p. 3.

${ }^{7}$ El primer documento que habla de esta puerta se remonta al año 916, según C. ESTEPA DíEZ, Estructura social de la ciudad de León. Siglos XI-XIII, León, 1977, p. 119 , nota 63.

${ }^{8}$ M. QUADRADO, Recuerdos y bellezas de España. Asturias y León, Madrid, 1885, p. 368, también aporta la denominación de Postigo, que es poco habitual.

${ }^{9}$ Sobre el abastecimiento de aguas en la época romana, véase, M. GoNZÁLEZ FLóREZ, "Historia del abastecimiento de aguas a la ciudad de León (I)",
} 
tos ramales ${ }^{10}$. Así fue a lo largo de la historia hasta hace poco tiempo. Durante el reinado de Carlos III, tan preocupado por la idea ilustrada de la salubridad pública, se hizo un encauzamiento de las aguas de varios manantiales hasta desembocar en el Arca Principal, que se construyó pegada a la cara interior de la muralla y justo al lado de Puerta Castillo ${ }^{11}$, como se puede ver en algunas fotos antiguas (lám. 5). Tanto el arca como la fuente aledaña se desmantelaron en el siglo pasado, haciéndose en 1977 en su lugar un pasadizo peatonal de pésimo gusto que vulnera el entorno monumen$\mathrm{tal}^{12}$. En memoria de la anterior función ubicada en este espacio queda una inscripción de la época, hoy descontextualizada por completo, en la que todavía se puede leer:

CAROLO III REGE. ANNO MDCCLXXXV. AQUIS COMUNI CENSU DUCTIS.

URBIS SALUTI AC SPLENDORI LEGIONENSES CIVES CONSULTUM VOLUERE

No tenemos ninguna descripción fehaciente de la apariencia inicial de Puerta Castillo, ni las excavaciones arqueológicas realizadas han aportado ninguna novedad al respecto. Es posible que la puerta romana

Tierras de León, no 41, León, 1980, pp. 17-20; M. SANTANDER, "Notas sobre el acueducto romano de León", $B S A A$, Valladolid, 1970, p. 466.

${ }^{10}$ Uno de ellos apareció en la Plaza de Puerta Castillo a raíz de las excavaciones realizadas por J. M. VIDAL ENCINAS, "Arqueología urbana en León: precedentes y aportaciones recientes", Archivos Leoneses, t. $\mathrm{XL}, \mathrm{n}^{\circ}$ 79-80, 1986, pp. 370-372.

11 M. GONZÁlez FlóREZ, "Historia del abastecimiento de aguas a la ciudad de León (II)", Tierras de León, nº 42, León, 1980, pp. 8-9.

${ }^{12}$ La solución de hacer un paso peatonal ha sido utilizada en otros lugares con problemas similares, pero obteniendo resultados muy distintos. Algunos ejemplos son analizados por J. GALLEGo RocA, "Las murallas y la ciudad. Uso, conservación y restauración”, La ciudad y sus murallas, Granada, 1996, p. 20. estuviera ubicada exactamente en el mismo lugar que la actual, y no descartamos que la torre cuadrangular de fábrica medieval que se levanta a su lado se corresponda con una anterior romana, formando parte del sistema defensivo de la puerta original ${ }^{13}$. Ahora bien, también es probable que en un principio su situación fuera algo más ladeada, pues entre la que ahora existe y el castillo hay un pequeño murete, de escaso grosor, aparejo tosco y desde luego en absoluto romano, que nos indica una fábrica muy posterior al resto de la muralla. Otra hipótesis apunta a que la entrada originaria tuviera dos vanos, lo mismo que la primitiva Puerta Obispo citada, y que en alguna de las reformas medievales se redujera a uno, correspondiendo con el existente hoy en día.

Desconocemos cuando desaparecería la primitiva portada romana. Algunos historiadores creen que los ataques de Almanzor y Abd al-Malik, entre finales del siglo $X$ y principios del siguiente, arrasaron la ciudad y destruyeron gran parte de la mura$11 a^{14}$. Hoy se tiende a creer que las tropas islámicas se dedicaron a aportillar las murallas para reducir al mínimo su función defensiva, no a destruirlas, entre otras cosas por el ingente trabajo necesario para echar abajo semejante fortificación ${ }^{15}$. ¿Destruirían en aquella época la puerta decumana?. Nada hay definitivo, como tampoco sabemos si la reforma que hizo el rey Alfonso V del recinto amurallado incluiría su reedifica-

\footnotetext{
${ }^{13}$ Las excavaciones realizadas por C. FERNÁNDEZ ALLER, cuyos resultados se recogen en sus Tesis Doctoral Legio VII Gemina. Aportaciones a la historia romana de León, Salamanca, 1972, no llegaron hasta encontrar el fundamento romano de la torre.

${ }^{14}$ M. RisCO, op. cit. La teoría de Risco es seguida por historiadores posteriores como L. MATEO MARCOS, Origen, evolución y decadencia del recinto amurallado de León, León, 1981, p. 26.

${ }^{15}$ E. BENITO RUANO, "Las murallas y cercas de la ciudad de León durante la Edad Media", en León medieval. Doce estudios, León, 1978, p. 30.
} 
ción, aunque Madoz recoge la tradición de que fue este rey quien reconstruyó las cuatro puertas, tras los destructores ataques de los musulmanes ${ }^{16}$.

En cualquier caso, ni la historiografía ni la documentación conocida hacen referencia en ningún momento a la fisonomía que tuvo Puerta Castillo hasta el siglo XVIII. Ahora bien, lo que sí podemos afirmar es que la puerta realizada en ese siglo coincidiría en su ubicación con la inmediatamente anterior, como demostraremos más adelante.

A mediados de la decimoséptima centuria, en el reinado de Fernando VI, su estado de conservación debía ser ruinoso y se decide su arreglo inmediato. En el ayuntamiento ordinario celebrado el 26 de marzo de 1757 se acordó contratar a un maestro de obras para que reconociera las Puertas de Santa Ana y Castillo, con el fin de dictaminar cuanto antes los reparos necesarios y solucionarlos:

... tratose sobre que allarse con alguna prezisa refizion que hazer en los arcos de la Puertas de Santa Ana y Puerta Castillo y acordo la Ciudad que el señor Dn. Pedro Lorenzana con maestro que sea de su satisfaczion lo mande reconozer y que de parte para el primer ayuntamiento a fin de que se pueda providenziar sobre su seguro ${ }^{17}$

$\mathrm{Al}$ mes siguiente ya estaban hechas las condiciones de la obra para arreglar los arcos que amenazaban ruina, que se hicieron públicas para que los maestros interesados pudieran hacer las convenientes ofertas a la baja sobre los 892 reales tasados:

...en bista asimismo de las condiziones puestas para los reparos de las puertas

\footnotetext{
16 P. MADOZ, Diccionario Geográfico-EstadísticoHistórico de España, t. X, Madrid, 1847, p. 195.

17 Archivo Histórico Municipal de León (desde aquí AHML), Actas Municipales, caja 73, n ㅇ, s/f
}

del Castillo y la de Sta. Ana ${ }^{18}$, es tanta la ruina que pareze amenazan sus arcos, acordo la Ciudad se publique esta refizion por el termino de nuebe dias sobre los ochozientos nobenta y dos reales en que se halla tasada $y$ que asi publicada se remate con interbenzion del Sr. Dn. Pedro Rodriguez Lorenzana ${ }^{19}$.

No obstante, las obras no se debieron iniciar, sin que sepamos las razones que motivaron tal demora, porque en el ayuntamiento de 14 de junio de 1758 la ciudad decidió componer Puerta Castillo y Puerta Moneda $^{20}$, afirmando que eran las que estaban en peor estado. El concejo cambió el plan inicial, sin que las actas municipales reflejen ninguna explicación al respecto, decidiendo ahora hacer la puerta norte completamente nueva, en vez de efectuar una mera reforma para solucionar los desperfectos. También desconocemos si se iniciaron los trabajos en santa Ana y cuáles fueron las intervenciones en puerta Mone$\mathrm{da}^{21}$, pues no se han encontrado datos documentales sobre estas obras proyectadas, ni existe en la actualidad memoria alguna sobre ellas.

Decidida la obra, los trabajos comenzaron en junio de 1758, incluyendo también la realización de la calzada correspondiente, que se llevaron a cabo con celeridad, pues ya estaban concluidos el siete de agosto del año siguiente ${ }^{22}$. El coste final ascen-

\footnotetext{
${ }^{18}$ La puerta de santa Ana era una de las puertas de la cerca medieval, no de la muralla romana.

19 AHML, Actas Municipales, caja 73, no 80, s/f.

${ }^{20}$ Ahora, sin que conozcamos la razón, no se vuelve a mencionar la de Sta Ana y se habla de Puerta Moneda, otra de las puertas de la cerca medieval leonesa.

${ }^{21}$ La única referencia a los reparos de Puerta Moneda, sin especificar los realizados, se encuentran en AHML, Sección de Propios y Arbitrios, caja 234, no 32, s/f: ... son data seiscientos y quarenta reales pagados por la refeccion ejecutada en los Arcos de Puerta Castillo y Moneda, en vista de la ruina que amenazaban, consta de condiciones y libranza del cavallero comisario a quien se encargo.

${ }^{22}$ Véase la nota 36.
} 
dió a 136.959 reales y ocho maravedíes, según recoge el documento municipal titulado Razon de lo pagado por los jornales, materiales y mas gastos de la Calzada y Arco de Puerta Castillo, como consta de las 59 libranzas siguientes $^{23}$.

Llama la atención la decisión de construir una nueva entrada en el recinto amurallado en una época tan tardía, algo infrecuente en las ciudades españolas alejadas de la frontera, las cuales mantenían una actitud laxa en relación con los sistemas defensivos. Por esta razón se convierte en uno de los pocos ejemplos que existen en España de una puerta barroca en su ubicación original, todavía adosada a la muralla. Si en aquellos momentos se optó por levantar de nueva planta una entrada monumental, tuvo que deberse a importantes y variadas razones. En primer lugar, como hemos visto, hay que tener en cuenta el estado de ruina que presentaba, que debía tener un peligro evidente de desplome cuando fue tratado en varias ocasiones en las reuniones del cabildo municipal. Por lo tanto, tenemos que presumir que la necesidad de demoler la obra antigua era muy urgente, para evitar males mayores, tanto para las personas que circulaban a través de ella como para la propia estructura de la muralla.

No obstante, esta no era una razón suficiente para sustituirla por otra, pues se pudo desmontar la vieja y aprovechar el espacio para hacer una calle que salvase sin impedimentos la frontera entre la ciudad y sus arrabales. Desde el siglo XVI se venía planteando en España la polémica sobre la conveniencia de mantener las puertas de las ciudades amuralladas, o derribarlas como un medio de nueva urbanización ${ }^{24}$. Por

\footnotetext{
${ }^{23}$ AHML, Sección de obras, caja 715, no 1, s/f.

${ }^{24}$ Así por ejemplo sucedió en Madrid, como lo estudia A. CÁmARA, "Modelo urbano y obras en Madrid
}

eso, la sustitución se tuvo que deber a que todavía desempeñaba su función original.

Las murallas fueron desde el principio algo consustancial a las ciudades, cumpliendo objetivos muy diversos, no sólo el militar y defensivo, algunos de los cuales han ido cambiando a lo largo de la historia. Fueron una línea divisoria que diferenciaba lo que estaba intramuros de lo que se situaba extramuros, o lo que es lo mismo, marcaban la distinción entre dentro y fuera, la ciudad y lo que no es ciudad. Sirvieron de frontera que delimitaba un espacio jurídico, administrativo, comercial y fiscal distinto, donde los ciudadanos gozaban de unos derechos que no tenían los que vivían en el mundo rural, continuando con estos valores incluso cuando dejaron de tener sentido defensivo. De esta manera, la muralla materializa la idea de una ciudad limitada o cerrada $^{25}$. En este sistema, la puerta cumple la misión de cierre de la ciudad, además de control y filtro, tanto de los hombres como de los bienes y productos mercantiles que puedan entrar o salir de ella.

A este respecto no podemos olvidar que León a mediados del siglo XVIII, en cuanto a extensión, poco había cambiado desde el medievo y por lo tanto todavía estaba prácticamente circunscrita al recinto amurallado, que estaba en plena vigencia como se puede comprobar en el famoso plano que incluyó el padre Risco en su Historia de la ciudad de León (lám. 3). Con esta configuración las puertas seguían conservando su funcionalidad, como constatamos en los documentos de la época, de los que extraemos algunos ejemplos. En diciembre del año 1756 se pagaron con cargo al producto de los arbitrios, ...treinta y un mil seis-

en el reinado de Felipe II", en Madrid en el contexto de lo hispánico, Madrid, 1992, p. 34-37.

25 A. ISAC, "Ciudad cerrada y ciudad abierta. La muralla en la historia de la ciudad", La ciudad y sus murallas, Granada, 1996, p. 67. 
cientos y ochenta a los seis porteros de la ciudad por el que les tiene señalado de quarenta ducados annuales a cada uno, que componen entre todos dos mil seiscientos y quarenta reales a el año y devengaron en los doce de las quentas $y$ esta liquidacion que fenecieron con diziembre de mil setecientos cinquenta y seis ${ }^{26}$. $\mathrm{Al}$ año siguiente, igual que sucedía todos los meses de diciembre de la época, los porteros menores de la ciudad pidieron que se les diera la propina acostumbrada por Navidad ${ }^{27}$. Unos años después, en marzo de 1761, libró la Ciudad al Portero maior y menores por dichas Pasquas de Resureccion de $61 \_96$ reales $^{28}$. Todo lo cual nos indica que las puertas tenían una misión importante para la ciudad, estando atendida cada una por un portero, que estaba a las órdenes del portero mayor. Al parecer, las puertas de la ciudad leonesa siguieron operativas, e incluso cerrándose durante la noche, hasta entrado el siglo XIX ${ }^{29}$.

Por último, afirmamos que la exigencia de construir una puerta nueva no lleva consigo la necesidad de hacerla monumental, si se hace así es por una intención muy precisa. Desde el renacimiento se consideraba que las murallas servían también para embellecimiento de la ciudad, y así Castillo de Bobadilla hablaba en 1597, en su Política para corregidores, de la importancia de los muros por el mucho lustre y ornato que se sigue de estar las fortalezas y murallas enteras y

\footnotetext{
${ }^{26}$ AHML, Sección de Propios y Arbitrios, caja 346, nº $1-58, \mathrm{~s} / \mathrm{f}$.

${ }^{27}$ AHML, Actas Municipales, caja 73, no 80, s/f

${ }^{28}$ AHML, Sección de Propios y Arbitrios, caja 332334 , nํ 5, fol. 391.

${ }^{29}$ J. L. MARTín GALINDO, La ciudad de León en el siglo XVIII. Biografía de una ciudad, León, 1959, p. 47. M. BRAVO GuARIDA, Rincones leoneses, León, 1979, p. 18, llega decir que se cerraban las diez puertas y los varios postigos de la ciudad tras el toque de queda que se daba en la torre de la parroquia de San Marcelo, a las nueve en invierno y a las diez en verano.
}

con almenas ${ }^{30}$; de forma parecida se expresaba en la misma fecha Pérez de Herrera cuando propuso hacer una nueva muralla para Madrid que había de servir por aora mas de ornato y guarda, que de gran fortaleza y defensa ${ }^{31}$. Lógicamente, el mayor interés ornamental de las fortificaciones se encuentra en las puertas, que pueden ser consideradas como la portada arquitectónica de la ciudad. Se realizaban con materiales más nobles, se adornaban con motivos escultóricos, siendo habitual la colocación de alegorías o estatuas simbólicas, y nunca faltaba en lugar prominente una inscripción alusiva a la ciudad, los ciudadanos o la autoridad bajo la cual se había construido. Su configuración revela la importancia del espacio al que da acceso y habla del valor específico de la urbe que se abre tras ellas, por eso los elementos utilizados en su composición tienen un sentido emblemático que debe ser especialmente cuidado, sin olvidar en su diseño el gusto propio de la época. Por todas estas razones, a las que hemos de añadir también las cuestiones derivadas de la poliorcética, las puertas ocupaban un destacado apartado en los tratados de arquitectura militar, con el fin de solucionar técnica y estéticamente sus múltiples significados y funciones.

En el caso que nos ocupa, la idea de la construcción partió del corregidor de la ciudad y del interés mostrado por el marqués de San Isidro, que fue nombrado comisario de la obra para llevarla a buen fin. El primer problema consistía en solucionar la financiación de la obra, máxime para una ciudad como León, que en aquellos momentos era una población en crisis y por tanto no disponía de suficiente capital líquido para afrontar una empresa de tal

\footnotetext{
${ }^{30}$ Citado por A. CÁMARA, "Murallas para la guerra y para la paz. Imágenes de la ciudad en la España del siglo XVI", Espacio, Tiempo y Forma, serie VII, $\mathrm{H}^{\mathrm{a}}$ del arte, t. 6, 1993, p. 151.

${ }^{31}$ Ídem, p. 172.
} 
envergadura. Las murallas eran, en principio, propiedad de la corona, pero su mantenimiento o reforma corrían habitualmente por cuenta del concejo, que podía incluso poner impuestos especiales para financiar los trabajos ${ }^{32}$. Para sufragar el coste de la edificación de Puerta Castillo, se decidió en principio aprovechar un excedente de dinero que había de las Rentas provinciales de la ciudad y su casco, que se administraban de cuenta del Común:

...el Sr. Marques de San Ysidro participo a la Ciudad como el Procurador Sindico Xeneral, acompañado de don Manuel Carnero Serrano, Diputado del Comun, habian pasado a participarle, como el Sr. Corregidor ha determinado que de los caudales sobrantes que han produzido las rentas probinziales de la Ciudad y su casco, que se administran de cuenta del Comun, se compusiese las dos salidas que tiene, asi por la puerta de Castillo, como por la que llaman de Moneda, que son las que se contemplan por mas prezisas por la mala disposizion en que se hallan, esponiendole que a este fin les havia mandado el Sr. Corregidor pasasen a estar con el sr. Marques con quien tratasen en el particular $y$ de acuerdo prozediessen a la disposizion del modo que se han de dirigir dichas obras de forma que se obserbe la mayor exactitud de ellas y que haviendo combenido en el asumpto tratado, lo pone en notizia de la Ciudad a quien dicho Sr. Corregidor ha encargado se participe para que por su parte de las disposiziones que tenga por correspondientes al aspecto publico y mejor ermosura de las obras respecto que los caudales tiene

-

32 Esto era así desde la Edad Media. El caso de León a finales del medievo lo estudia I. GONZÁLEZ GALLEGO, "Las murallas y los puentes de León en el siglo XIV", en León y su Historia, t. IV, León, 1977, p. 367-404. A partir del renacimiento la tendencia era que las pagaba el reino o la ciudad, según a quién beneficiase más la nueva fortificación, así lo explica A. CÁMARA, Fortificación y ciudad en los reinos de Felipe II, Madrid, 1998, p. 194-197. determinado sacarlos del fondo referido, y enterada la Ciudad de lo asi espuesto por el Sr. Marques, acordo pasase a dar al Sr. Corregidor las devidas grazias por el zelo y actibidad con que mira el bien del publico, y que desde luego nombra por su comisario a dicho Sr. Marques para que acompañe al Sr. Corregidor en todo quanto sea nezesario $y$ deba ejecutarse en dichas obras y de lo que ocurriese de parte ${ }^{33}$.

Además, se utilizaron también otros caudales provenientes de las Cuentas de Propios, según se recoge en la contabilidad del año $1760^{34}$. Al considerar la obra de utilidad pública también se hizo uso de la facendera, tras la que se obsequiaba a los vecinos que habían trabajado en la construcción con hogazas de pan y jarras de vino $^{35}$.

En los documentos que se conservan nada se dice acerca del arquitecto que fuera el autor intelectual del proyecto, que por desgracia permanece anónimo, ni sabemos quien redactó las condiciones de la construcción; sin embargo, ahora estamos en disposición de poder afirmar que el maestro de obras que llevó a cabo todos los tra-

33 AHML, Actas Municipales, caja 73, n ㅇ, s/f

${ }^{34}$ AHML, Sección de Propios y Arbitrios, caja 234, nº 32, s/f:

...Quentas de las rentas de Propios de esta ciudad de Leon, año de 1760.

[al margen] Refeccion en los arcos de las Puertas de Castillo y Moneda.

... son data seiscientos y quarenta reales pagados por la refeccion ejecutada en los Arcos de Puerta Castillo y Moneda, en vista de la ruina que amenazaban, consta de condiciones y libranza del cavallero comisario a quien se encargo.

${ }^{35}$ AHML, Sección de obras, caja 715, n 1, s/f:

... Por 89 ogazas de trigo de a ocho libras que se gastaron con los vezinos de la jurisdizion que vinieron a la fazendera en la primera semana __ 125 reales.

... Sacaronse de la taberna de Manuel Rodriguez, vezino desta ciudad, para la fazendera de la calzada de Puerta Castillo, ochenta cantaras y media de vino tinto... Asi mismo se sacaron de la taberna de don Gonzalo de la Vega para la misma fazendera, treinta y tres cantaras y media de vino... 
bajos hasta su conclusión fue Bernardo Miguélez, ya que así lo recoge la documentación $^{36}$.

Para iniciar la edificación era necesario desmontar primero la puerta antigua que estaba en ruina, pues no debemos olvidar que la actual sustituye a otra anterior ubicada en el mismo lugar. Para hacer este trabajo se contrató a una cuadrilla ajena al maestro de la obra, pues hay en las cuentas unas partidas específicas que recogen los pagos correspondientes:

... a los que tienen ajustada la demolizion de la puerta se les dieron doszientos reales a quenta

... a los del desmonte de la puerta 156 rs. con que se les acavo de pagar los mil rs. en que se ajusto desmontar dicha puerta, y los seiszientos rs. en que se ajustaron el abrir todos los zimientos desde media calzada asta el fin de ella $a^{37}$.

\section{LA NUEVA PUERTA CASTILLO}

El discurrir de los años, la contaminación de todo tipo y la desidia de las instituciones han hecho mella en Puerta Castillo. Su deterioro llegó a tal grado que empezaron a desprenderse fragmentos de los elementos superiores, hasta que en octubre de 2000 el ayuntamiento procedió a su desmontaje parcial (compárese las láminas 1 y 2), de manera que en la actualidad está incompleta y mermada de significado, a la espera de la necesaria restauración. Por esta razón el análisis siguiente se ciñe a la confi-

${ }^{36}$ AHML, Sección de obras, caja 715, no 1, s/f:

... Pagara V M por este sr. dn. Thomas Rodriguez Lopez a el sr. Bernardo Miguelez maestro de las obras que se ejecutaron por quenta de este Comun los quatro mill seiscientos veinte y seis rs. y veinte y siete mrs. de vellon que importa la memoria antecedente que se aran a VM buenos en sus cuentas; Leon y agosto siete de mil setezientos zinquenta y nuebe.

${ }^{37}$ AHML, Sección de obras, caja 715, no 1, s/f guración original de la puerta, cuando todavía estaba íntegra.

Fue construida con buena sillería, utilizando dos tipos de piedra distintos, lo que ofrece un interesante juego plástico por la buscada combinación de colores y texturas. La parte inferior de la estructura, hasta la línea de imposta desde donde arranca el arco, está realizada con una caliza dura y resistente, que presenta un irregular y vistoso veteado rosáceo; el resto se hizo con la típica caliza de Boñar -la más utilizada en la arquitectura monumental leonesa a lo largo de la historia-, blanda y fácil de trabajar, pero también por eso la que tiene una peor vejez. Los elementos ornamentales, escultura y cartelas, también son de esta misma piedra, y de ahí le vienen la mayoría de sus males.

La puerta se hizo para que quedara en el mismo plano que la cara exterior de la muralla. Hoy la transición entre ambas estructuras es abrupta, cuadrando mal la sillería de la obra dieciochesca con los sillarejos y los cantos rodados del paredón, pero suponemos que en su día éste estaría revocado, como era habitual en las construcciones de la época, ocultando las imperfecciones del aparejo y proporcionando al conjunto un cuidado acabado.

En la ejecución de la obra se reutilizaron materiales de la estructura anterior, en una práctica que se puede considerar frecuente en aquel tiempo, pudiéndose comprobar como hay algunos sillares que por forma o tamaño desentonan con el conjunto. Pero hay dos, situados en la cara exterior al lado de la cartela de la izquierda, especialmente llamativos porque tienen inscripciones medievales fechadas en los siglos XII y XIII ${ }^{38}$. Con toda probabilidad

\footnotetext{
${ }^{38}$ Las inscripciones han sido estudiadas por L. MARTínez Ángel, "Puerta Castillo de León. Noveda-
} 
tienen su origen en alguna de las reformas que se hicieron en la muralla durante la Edad Media, pero sería aventurado pensar que formaron parte de una hipotética puerta medieval, que hubiera sustituido a la primitiva romana en alguna reforma ${ }^{39}$.

En la parte interior, hacia el lado izquierdo, todavía se conservan una serie de sillares antiguos que forman una especie de pilar, situado entre la obra dieciochesca y el murete aparejado con canto rodado que la une al castillo (lám. 8). Su estado actual no permite catalogarlo de manera definitiva como fábrica medieval o romana, pero sin duda pertenecía al sistema de fortificación. Si los romanos hubieran hecho aquí una entrada con vano geminado, entonces los restos se corresponderían con el pilar central que dividiría en dos la abertura. También pudiera ser que los citados sillares fueran los restos de la primitiva muralla romana, que quedaron aislados tras la instalación del arca principal de distribución de aguas, realizada en la época de Carlos III, ya citada.

La puerta se conforma mediante un amplio vano de 5,85 metros de luz y una altura cercana a los 8 metros, cubierto con arco de medio punto sin ningún tipo de molduras, de 1,95 metros de grosor. Se apoya sobre dos pilares lisos, que se ensanchan en su parte inferior a modo de zócalo; sin basas ni capiteles, unas simples molduras marcan la línea de imposta. Al exterior, las enjutas del arco presentan sendas cartelas de contornos sinuosos y trazado irregular, de gusto barroco cercano a la rocalla, que se completan con otras en los

\footnotetext{
des epigráficas medievales", Tierras de León, no 114 , León, 2002, pp. 95-103.

${ }^{39}$ Hay constancia documental de obras en la muralla, pero no de la realización de ninguna puerta, J. A. GUTIÉRREZ GONZÁLEZ, Fortificaciones y feudalismo en el origen y formación del reino leonés, Valladolid, 1995, pp244-245.
}

frentes de la clave del arco. Un friso de molduras elementales y recorrido por una línea ininterrumpida de dentículos, enrasa con la altura de la muralla, dando paso a los adornos superiores. Culmina el conjunto una efigie del mítico visigodo Pelayo, vestido de guerrero, ataviado con una amplia capa de aspecto real y tocado con un caso que originalmente se adornaba con plumas $^{40}$; empuña una espada con la mano derecha y la izquierda sujeta un escudo de carácter ornamental que tiene en su frente un león rampante, emblema de la ciudad. El deterioro de la estatua no permite hacer una descripción completa, ni, por supuesto, una valoración artística.

Gracias a la documentación existente conocemos el nombre del escultor que la realizó, Francisco Velasco, quien cobró por ello al menos 1.500 reales $^{41}$. Este artífice no ha sido todavía suficientemente estudiado, por lo que es prácticamente desconocido y nada podemos decir acerca de su estilo. Pudiera ser el mismo Velasco, del que los documentos no aportan el nombre de pila, que pretendió hacer la decoración escultórica del claustro basilical de San Isidoro de León ${ }^{42}$, o quien hizo la imagen de Santa Marina y el crucifijo del retablo mayor de la parroquia de Santa Marina del Rey ${ }^{43}$.

\footnotetext{
${ }^{40}$ AHML, Sección obras, caja 715, no 1, s/f: ...La espada y las plumas del casco costaron 70 reales.

${ }^{41}$ AHML, Sección de obras, caja 715, no 1, s/f:

... Francisco Velasco, por quenta de su trabajo 200 rs.

Ultima relazion de lo gastado en la calzada de Puerta Castillo en las 3 ultimas semanas que fueron la que cumplio en 22 de jullio, la segunda en 29 del dicho y la ultima en 5 de agosto de 1759

... a Francisco Belasco mill trescientos rs. con que se le acavo de pagar la estatua y los escudos

${ }^{42}$ Véase E. MORAIS VALLEJO, "Reinas e infantas en la decoración escultórica del claustro basilical de san Isidoro de León", Estudios humanísticos, no 22, León, 2001, pp. 211-230.

43 F. LlAMAZARES RODRÍGUEZ, El retablo barroco en la provincia de León, León, 1991, p. 376.
} 
La figura de Pelayo se levanta sobre un voluminoso pedestal rectangular que sirve para poner en su parte exterior una erudita inscripción que analizamos más adelante, y en la posterior una pequeña hornacina, hoy vacía, que a falta de referencias documentales suponemos que servía para albergar alguna imagen religiosa a la que se dedicaba la puerta. A ambos lados se colocaron sendas formas de diseño geométrico basado en figuras cúbicas y piramidales, que sirven para equilibrar la composición, de la que la estatua es su eje de simetría. Esta especie de pináculos se hicieron combinando los dos tipos de piedra citados, remarcando con la bicromía su carácter exornativo y forzando la acumulación de elementos decorativos en la parte superior, en un esquema propio del barroco.

El vano estaría cerrado con un portón de hojas de madera, del que no ha quedado memoria alguna, pero que sin duda existió dada la funcionalidad demostrada. A pesar de que algunos autores han querido ver en unas argollas de hierro, que todavía se conservan, los quicios de las puertas ${ }^{44}$, creemos que por su ubicación no es factible, siendo más probable que sean soportes para mástiles o estandartes.

En su conjunto, la obra, realizada en el marco del barroco académico de mediados del siglo XVIII, quiere tener la apariencia de un arco de triunfo, para lo cual no le falta ni morfología, ni simbología.

La inscripción del citado pedestal, escrita con buena grafía de letras capitales que en su día estuvieron doradas, presenta un lamentable deterioro por lo que ahora no se puede leer en su totalidad ${ }^{45}$. De los cinco sillares verticales que componen el

\footnotetext{
${ }^{44}$ M. BRAVO GUARIDA, Rincones..., p 16

${ }^{45}$ AHML, Sección de obras, caja 715, no 1, s/f:

...por dorarlas y escrivir las letras de la inscripcion grande _ 70 reales.
}

campo de escritura uno está totalmente dañado, habiendo desaparecido todas las letras escritas en él, así como la última línea (lám. 11). Acudimos por ello al padre Risco y a Antonio Ponz que la leyeron cuando todavía estaba incólume y la transcribieron de la siguiente manera ${ }^{46}$.

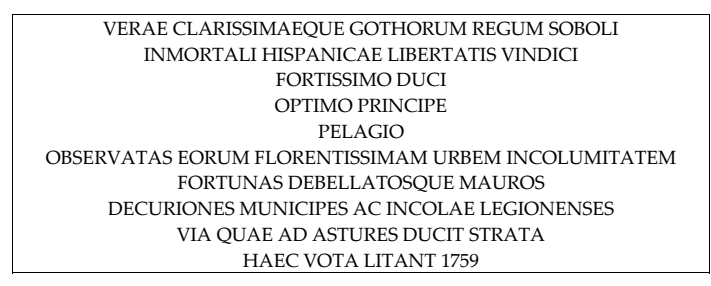

Podría traducirse por: Al muy poderoso jefe y excelso príncipe Pelayo, del linaje auténtico y preclaro de los reyes godos, protector de la libertad de la inmortal Hispania. Honradas las riquezas de quienes hicieron incólume la floreciente ciudad y vencieron a los sarracenos; los senadores, autoridades municipales $y$ vecinos de León ofrecen sus mejores augurios en la salida del camino que conduce a Asturias. 1759.

La inscripción presenta una interesante serie de elementos dignos de estudio, alguno de los cuales supera las intenciones de este artículo.

En primer lugar llama la atención el protagonismo histórico que se concede a Pelayo en la reconquista de la ciudad de León contra los musulmanes, que la historiografía actual descarta por completo, pero que en la Edad Moderna algunos historiadores tenían como cierto. La historia de León escrita por Athanasio de Lobera, cuenta en el capítulo segundo Como León fue ganada de los moros y buelta a recobrar por los

\footnotetext{
${ }^{46}$ M. RisCO, op. cit., p. 128; A. PONZ, Viage de España, Madrid, 1787, p. 241.
} 
christianos $^{47}$, afirmando que Pelayo, con hábiles maniobras militares dignas de un valeroso jefe, ganó la ciudad para la causa cristiana. No sólo contradice a Ambrosio de Morales $^{48}$, que ya había negado con decisivas razones tal participación, sino que elabora una alambicada argumentación basada en algunos historiadores anteriores para demostrar la participación del caudillo godo en el resurgimiento de la ciudad leonesa. Da un valor incontestable a la historia del Alcayde Albulcacin Tarif Albentarique $^{49}$-supuesto historiador contemporáneo de la reconquista, que traduxo de aravigo en romance Miguel de Luna, interprete del Rey don Philippe segundo nuestro señor-, la cual traslada a su texto de manera litera $^{50}$.

Por lo tanto, las referencias históricas están acordes con una línea historiográfica concreta de la época, que, por otra parte, interesaba también para enlazar a la cabeza del reino de León con el mítico iniciador de la restauración del cristianismo en España. Además, Pelayo es un personaje utilizado como el eslabón necesario que unía la cadena histórica entre la antigua monarquía de los godos y la moderna, en una línea continua que llegaba hasta los borbones, que habían entrado en la historia española de manera indirecta.

Valerse de falsas historias, en realidad leyendas de carácter mítico, que pretenden otorgar un origen singular a ciertas ciudades hispánicas, fue una corriente habitual durante gran parte de la

\footnotetext{
${ }^{47}$ A. DE LOBERA, Grandezas de la muy antigua e insigne ciudad e iglesia de León, Valladolid, 1596, fol. 168 r. - $176 \mathrm{v}$.

${ }^{4}$ A. MoRALES, Viage de Ambrosio de Morales por orden del rey $D$. Phelipe II a los Reynos de León y Galicia y Principado de Asturias, Madrid, (1572), ed. facsímil de 1977.

${ }^{49}$ Nombre de un falso historiador árabe inventado a finales del siglo XVI por Miguel de Luna.

${ }^{50}$ A. DE LOBERA, Grandezas..., p. 173 r.
}

Edad Moderna para presentar una imagen épica del pueblo español y una explicación de los hechos históricos con intención moralizante. $\mathrm{Al}$ otorgar un origen glorioso a la fundación de la ciudad, muchas veces colocando la tradición goda por encima de la musulmana como en este caso, se presentaban una serie de valores simbólicos, con una base ética y moral, que se quieren transmitir al pueblo ${ }^{51}$. Proponiendo a Pelayo en el papel de refundador de la ciudad ${ }^{52}$, se designaba a un personaje como ejemplo a seguir en la superación de la tiranía y la liberación de las cadenas de la religión musulmana, que habían subyugado a España. La resistencia contra el invasor islámico y el esfuerzo de una ciudad durante la reconquista, son hechos que en las historias de las ciudades españolas son exaltados y valorados como algo peculiar y en relación con la fuerza de la ciudad como comunidad, resaltado por el mérito de sus ciudadanos más representativos, quienes ennoblecen con su presencia a la propia ciudad $^{53}$.

La utilización de la figura de Pelayo hay que ponerla en relación con un determinado ambiente cultural e ideológico característico del reinado de Fernando VI, perfectamente reflejado en el programa escultórico del Palacio Real Nuevo de Madrid, que puede servir de ejemplo paradigmático ${ }^{54}$. En efecto, para tan emblemáti-

\footnotetext{
${ }^{51}$ Estas fabulaciones, que pueden llegar a entroncar el nacimiento de las ciudades incluso con los dioses de la antigüedad, lo analiza S. QUESADA, La idea de ciudad en la cultura hispana de la Edad Moderna, Barcelona, 1992, en su capítulo 4, "Mitos, símbolos y astrología en los orígenes y desarrollo de la ciudad", pp. 59-70.

52 Las crónicas de las ciudades en la Edad Moderna solían tener un héroe famoso que servía de ejemplo y aportaba conciencia histórica, S. SEBASTIÁN, Arte y humanismo, Madrid, 1978, pp 254-56

53 S. QUESADA, La idea de ciudad..., p. 108.

${ }^{54}$ La serie escultórica del Palacio Real ha sido ampliamente estudiada por F. J. PLAZA SANTIAGO, Investi-
} 
co lugar el benedictino Martín Sarmiento ideó una decoración con patente deseo de ostentación pública ${ }^{55}$, como si fuera un nuevo templo de Salomón ${ }^{56}$, y al mismo tiempo la "España armada". Allí estarían representados todos los monarcas españoles, desde los míticos hasta Fernando VI -con especial interés por vincular a la dinastía borbónica-, emparentados con emperadores romanos y héroes de la Mitología; sería una especie de libro de mármol en el que el pueblo aprendería la historia de España a través de sus reyes ${ }^{57}$. Prueba de que el concepto era propio de una determinada época es que las estatuas fueron retiradas al poco de ponerlas, por una orden de Carlos III firmada el 8 de febrero de 1760, por encontrarlas contrarias a la cultura neoclásica que preconizaba el nuevo monarca ${ }^{58}$.

La serie escultórica se adjudicó en 1749 a Juan Domingo Olivieri y Felipe de Castro, que fueron ayudados por otros escultores, entre los cuales se encontraba

gaciones sobre el Palacio Real Nuevo de Madrid, Valladolid, 1975.

${ }^{55}$ MARTín SARMIENTO, Sistema de adornos de escultura interiores y exteriores para el Nuevo Real Palacio de Madrid, publicado parcialmente por F. J. SÁNCHEZ CANTÓN, en "Opúsculos gallegos sobre Bellas Artes de los siglos XVII y XVIII", Colección de Bibliófilos gallegos, Santiago de Compostela, 1956. Recientemente se ha publicado una transcripción completa con introducción y notas de J. ÁlVAREZ BARRIENTOS Y C. HERRERO CARRETERO, Madrid, 2002.

${ }^{56}$ S. MUNIAIN EDERRA, "El Sistema de adornos del padre Sarmiento para el Palacio Real de Madrid: Fernando VI como nuevo Salomón", en Un reinado bajo el signo de la paz, Fernando VI y Bárbara de Braganza, Madrid, 2003, pp. 119-134; Idem, El programa escultórico del Palacio real de Madrid y la Ilustración española, Madrid, 2000.

${ }^{57}$ J. J. MARTíN GONZÁLEZ, Escultura barroca en España, 1600-1770, Madrid, 1983, p. 399

${ }^{58}$ Algunas fueron posteriormente colocadas en la plaza de Oriente, delante del Palacio; otras adornan plazas y jardines de diversos lugares de España y las menos han vuelto a su primitivo lugar. Véase F. J. PLAZA SANTIAGO, Investigaciones..., pp. 209-212
Juan de Villanueva, encargado de realizar la estatua de Pelayo ${ }^{59}$. Aunque la efigie madrileña y la leonesa no tienen muchas similitudes estilísticas, sin embargo si hay un cierto parecido, seguramente por tener una misma fuente iconográfica. Martín Sarmiento dejó escritas unas indicaciones para hacer las representaciones reales, aconsejando para Pelayo lo siguiente:

Cara seria, rostro y aspecto marcial. Vestido como semirromano. Cabello largo. En la cabeza un morrión y en él encajada, no la diadema sino la corona, y con gracia. Con escudo a la izquierda y en él la cara de Gaudiosa, su mujer. En la derecha una espada larga y muy ancha en ademán de descargar el golpe, y con cruz por guarnición, al modo de la de San Fernando. Si pudiere ser, a los pies una cabeza de rey mahometano con su turbante $^{60}$.

En segundo lugar destacamos la fuerte carga intelectual que acredita el anónimo personaje que redactó o inspiró la inscripción latina. Detrás de ella apreciamos un considerable conocimiento de la antigüedad clásica. Así lo demuestran las frases utilizadas para ensalzar a Pelayo, que parecen sacadas literalmente de un monumento conmemorativo romano, necesariamente empleadas por algún erudito que tuviera notables nociones de epigrafía clásica. En el mismo sentido nos orienta la alusión a los buenos augurios, entroncada directamente con la tradición romana. Todas estas menciones a la antigüedad adquieren mayor significado cuando nos percatamos de la ausencia total de cualquier

\footnotetext{
${ }^{59}$ Este escultor realizó también las estatuas de Ramiro III, Alfonso VIII, Felipe III y Fernán González. Sobre su obra véase, J. J. MARTÍN GONZÁLEZ, Escultura barroca..., pp. 379-380; J.L. MORALES MARÍN, "La escultura española del siglo XVIII", en Summa Artis, t. 27,Madrid, 1984, p. 375-376

${ }^{60}$ J. Álvarez BARRIENTOS y C. HERRERo CARRETERO Sistema de adornos del Palacio Real de Madrid. Martín Sarmiento, Madrid, 2002, p. 252.
} 
alusión religiosa, ya que en ningún momento se citan advocaciones cristianas ni protecciones celestiales, como era corriente en obras similares.

Pero no sólo evidencian un conocimiento del pasado clásico, sino también atención y afecto. Las referencias al mundo romano adquieren un valor de linaje, pues con ellas también se está demostrando el pasado clásico de la ciudad, con unas raíces romanas que la entroncan con orígenes míticos de la antigüedad. Si la puerta se construyó gracias al patrocinio del rey Fernando VI, si en ella se elogia al reconquistador Pelayo y se hace una alusión al mundo romano, se está ensalzando esa cadena directa que enlaza la monarquía española con los principios de la historia.

Constatamos también que subyace una actitud que anuncia la mentalidad ilustrada, todavía minoritaria en aquellos momentos en España y por eso más extraña en una pequeña ciudad española de mediados del siglo XVIII. Los estudios históricos sobre esta época en León son todavía muy escasos y no es posible aventurar ninguna hipótesis al respecto; cuando el conocimiento sea más amplio podremos determinar si hubo aquí un grupo de intelectuales dedicados a la investigación del mundo clásico, capaz de crear el ambiente necesario para alumbrar semejantes obras.

A la hora de realizar inscripciones, como la que ahora nos ocupa, hay varias maneras de afrontar la cuestión. Una de ellas, poco académica pero al parecer bastante frecuente, la encontramos en los escritos de Martín Sarmiento ${ }^{61}$ :

Lo más a que pudiera arribar mi cortedad, y sin experiencia, después de muchísimo tiempo de aplicación, estudio y trabajo

\footnotetext{
${ }^{61}$ J. Álvarez Barrientos y C. Herrero Carretero Sistema de adornos..., pp. 145-146
}

sería a coser muy mal algunos centones de otras inscripciones antiguas. He observado que aun muchos eruditos se han aprovechado de este artificio, y aun del de copiar inscripciones ajenas... Si los eruditos y ejercitados en inscripciones se valen de semejante recurso, ¿qué podría hacer yo...?

No obstante, había en España a mediados del siglo XVIII, una serie de intelectuales de reconocido prestigio, incluso internacional, que se dedicaban al estudio de la epigrafía clásica, pudiendo venir por esa vía el enfoque erudito de nuestra inscripción ${ }^{62}$. Más adelante, en el reinado de Carlos III, se prodigaron las inscripciones de carácter clasicista en las obras públicas, de las que ya vimos un ejemplo, hasta hacerse habituales.

Otra cuestión llamativa es la mención que se hace a la dirección del camino. Al ser ésta la salida norte de la ciudad, se puede considerar como el punto kilométrico cero de la vía que conduce hacia Asturias, que, por cierto, todavía en aquellos años no era un camino de ruedas sino de herradura, según lo muestra el mapa de 1758 realizado por José Matías Escribano. De esta manera, la comunicación asturiana se convierte en una razón más para que sea Pelayo el protagonista máximo del monumento.

Las restantes cartelas hacen referencia a la fecha de ejecución y a las autoridades que hicieron posible la obra. El lado exterior de la clave del arco, por ser un lugar privilegiado, se destina a constatar el monarca bajo cuyo poder se construyó la puerta, así como la fecha de su inauguración, todo recogido en una cartela en forma de espejo ovalado y con adorno de cueros

\footnotetext{
${ }^{62}$ Sirva de ejemplo la epístola escrita en 1756 por GREGORIO MAYANS I SISCAR, Introductio ad veterum inscriptionum historiam litterariam, considerada un hito bibliográfico de la historia de la epigrafía como disciplina en el siglo XVIII. Véase la edición de L. ABAD Y J. M. ABASCAL, Madrid, 1999.
} 
recortados. Su deterioro es tal que hoy no se puede leer en su totalidad, así que seguimos la transcripción que hizo Miguel Bravo Guarida a principios del siglo $X X^{63}$

\begin{tabular}{|c|}
\hline REINANDO \\
LA MAGESTAD \\
DEL SEÑOR DON \\
FERNANDO VI. \\
AÑO 1759 \\
\hline
\end{tabular}

En la parte posterior de la misma clave vuelve a repetirse la fecha, esta vez en el espacio que rodean unas serpientes enroscadas y de aspecto fiero:

\section{AÑO DE 1759.}

Tampoco se pueden leer por completo los letreros de las enjutas, ya que algunas partes han desaparecido y otras son difíciles de interpretar por su lamentable estado de conservación. Como nadie transcribió las inscripciones literalmente antes de su irreversible deterioro, nosotros aventuramos una hipótesis, desarrollando las abreviaturas y supliendo las letras que faltan. $\mathrm{Su}$ lectura se hace teniendo en cuenta que los renglones de la cartela izquierda continúan en los de la derecha:

SIENDO INTENDENTE
REINO EL SEÑOR
PRADO I MALLO
BRIGADIER DE LOS
DE SU MAGESTAD
REALES GUARDIAS
INFANTERIA

GENERAL DE ESTE DON FERNANDO MARQUES DE VILLEL REALES EXERCITOS CAPITAN DE SUS ESPAÑOLES DE

\footnotetext{
${ }^{63}$ M. BRAVo GuARIDA, Rincones leoneses, León, 1979, p. 17.
}

En ellas se alude a Fernando de Prado, marqués de Villel, bajo cuyas ordenes se ejecutó. Este personaje era el intendente general de León, cargo institucional de ámbito provincial, instaurado por los borbones en la reforma administrativa iniciada a principios del siglo XVIII. El intendente estaba llamado a heredar las funciones del corregidor además de asumir otras nuevas, todas recogidas en la Ordenanza de 1749 firmada por Fernando VI. Entre ellas destacaban las labores de justicia, hacienda, guerra y policía, formar mapas geográficos de la región o hacer relaciones de los recursos de su demarcación, además de velar por el fomento de la industria, comercio y agricultura en el territorio de su jurisdicción ${ }^{64}$. Conviene recordar aquí que José Carvajal y Lancáster, Secretario de Estado de Fernando VI, estableció la real fábrica de tejidos e hilados de León, una operación más para llevar a cabo su política económica mercantilista, de trascendencia para la economía leonesa ${ }^{65}$.

Concluyendo, hemos visto la renovación de una puerta del recinto amurallado de León, que se aprovechó para ofrecer una nueva imagen de la ciudad que hay tras ella. No en vano las puertas en las murallas siempre fueron un elemento urbano de primer orden, por ser el acceso a un espacio

\footnotetext{
${ }^{64}$ V. CASAls Costa y H. CAPEl SÁEZ, "La ingeniería y la ciencia a la conquista del territorio" en Un reinado bajo el signo de la paz, Fernando VI y Bárbara de Braganza, Madrid, 2003, p. 320.

${ }^{65}$ De la fábrica construida en esta época ya sólo queda la portada monumental, colocada en otro lugar distinto del original, véase, E. MORAIS VALLEJO, "El traslado de edificios monumentales. El caso de León durante la etapa franquista" De Arte, no 1, León, 2002, pp. 125-128; M. D. CAMPOS SÁNCHEZ-BORDONA y J. PÉREZ GIL, "De recinto regio a fábrica textil. Las transformaciones de los palacios reales de León en el siglo XVIII", De Arte, no 2, 2003, pp. 179-180. Sobre la historia de la fábrica, J. L. MARTíN GALINDO, La ciudad de León en el siglo XVIII, León, 1959, pp. 52-55; también en AA VV, Historia de León. Edad Moderna, León, 1999, pp. 388-392.
} 
delimitado, actuando como si fueran la portada del gran edificio que es la ciudad. En este caso la obra es modesta y no alcanza una categoría artística descollante, entre otras razones porque una pequeña ciudad de la época no podía disponer de capital suficiente para realizar grandes monumentos, pero no por ello tiene menos interés.

En el análisis de la obra hemos tenido en cuenta la índole emblemática que tenían las puertas de las murallas, y más cuando éstas cercaban una ciudad histórica. Por eso están cargadas de un simbolismo que se tiene que condensar en unos pocos elementos de gran significación, con los que deben transmitir inequívocamente las ideas de sus promotores ${ }^{66}$. Estamos, una vez más, ante una utilización elocuente y retórica de diferentes recursos para conseguir la característica persuasión propia del barroco.
${ }^{66}$ A. CÁMARA, "Murallas para la guerra y para la paz. Imágenes de la ciudad en la España del siglo XVI", Espacio, Tiempo y Forma, serie VII, $\mathrm{H}^{\mathrm{a}}$ del arte, t. 6, 1993, p. 152.
Valerse de personajes relevantes que son un ejemplo a seguir para el pueblo, como es el caso de Pelayo, es siempre una manera de enaltecer la ciudad que les hace monumentos. Hacer monumentos originales es una forma de embellecer la ciudad. Con la unión de ambos componentes se consigue ofrecer la imagen de una ciudad con valores éticos y estéticos.

Al ser una puerta que no está pensada para la guerra, ni está concebida según las teorías modernas de la arquitectura militar, tiene intención urbanística y de ornato, además de la señalada carga simbólica e ideológica, en un período histórico marcado por la paz y la consecución de la prosperidad $^{67}$.
${ }^{67}$ La paz fue uno de los principios del reinado y una de las razones que permitieron una mayor producción artística, gracias al camino de modernización y progreso emprendido. A. BONET CORREA, "Un reinado bajo el signo de la Paz", Fernando VI y Bárbara de Braganza (1746-1759), Madrid, 2003, pp. 1-28. 


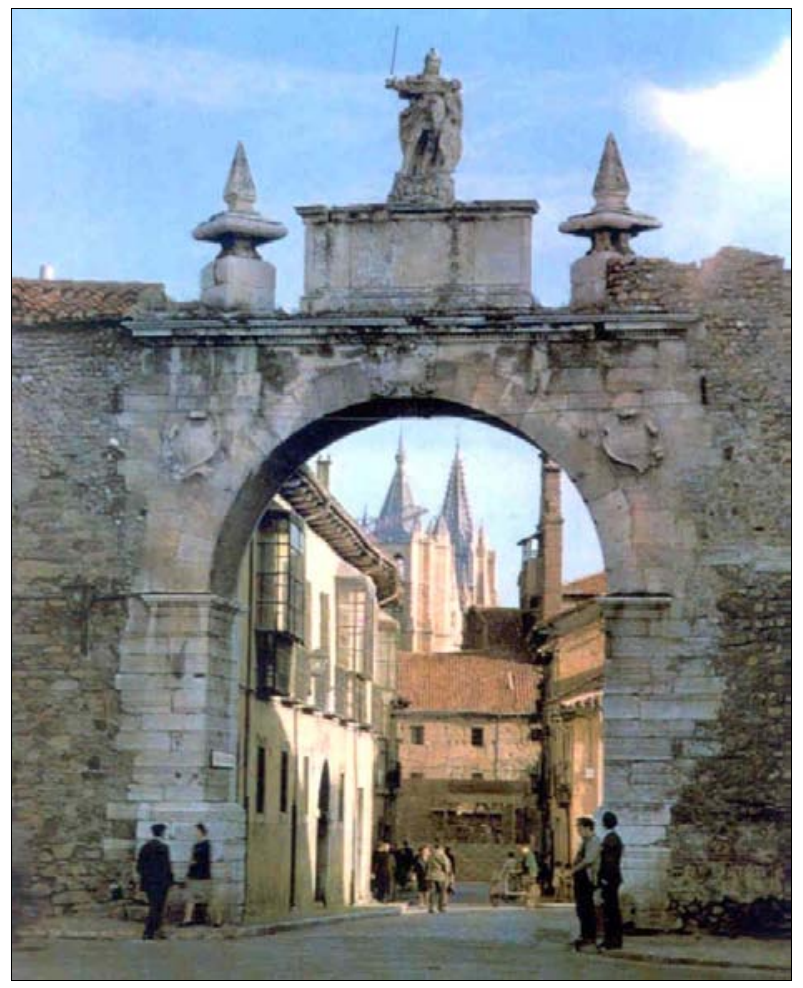

- Lám 1. Puerta Castillo antes de desmontar el remate

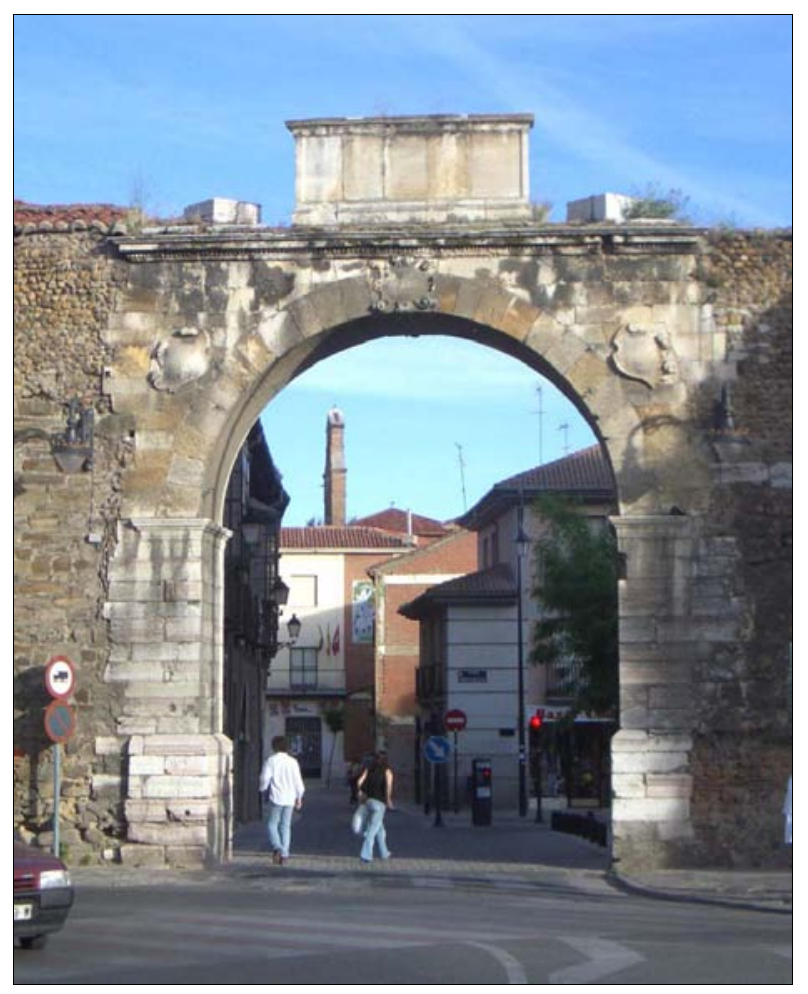

- Lám. 2. Puerta Castillo en la actualidad 


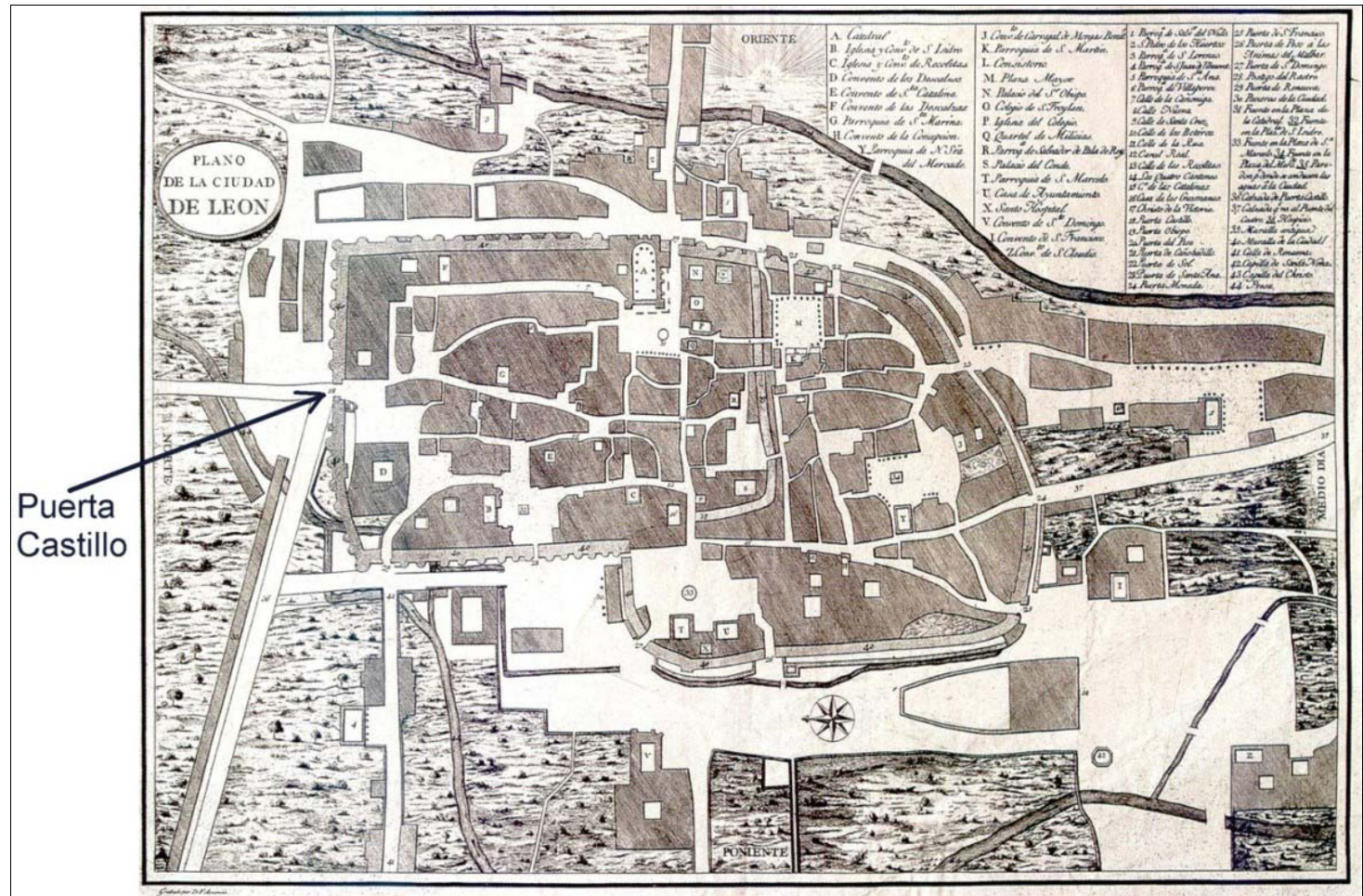

- Lám. 3. Plano de León en el siglo XVIII

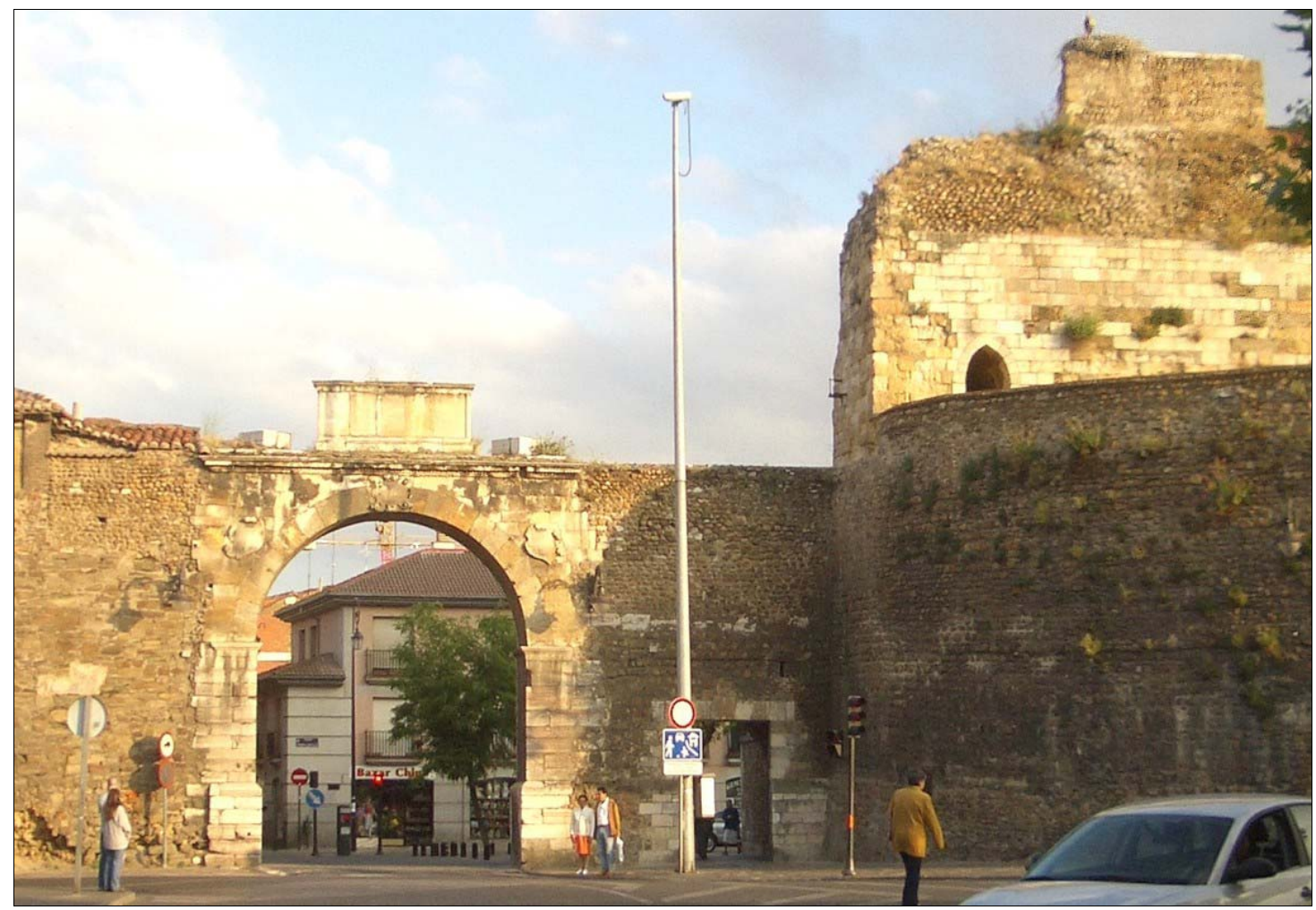

- Lám. 4. Vista de Puerta Castillo, el pasadizo peatonal y la torre cuadrada del castillo 


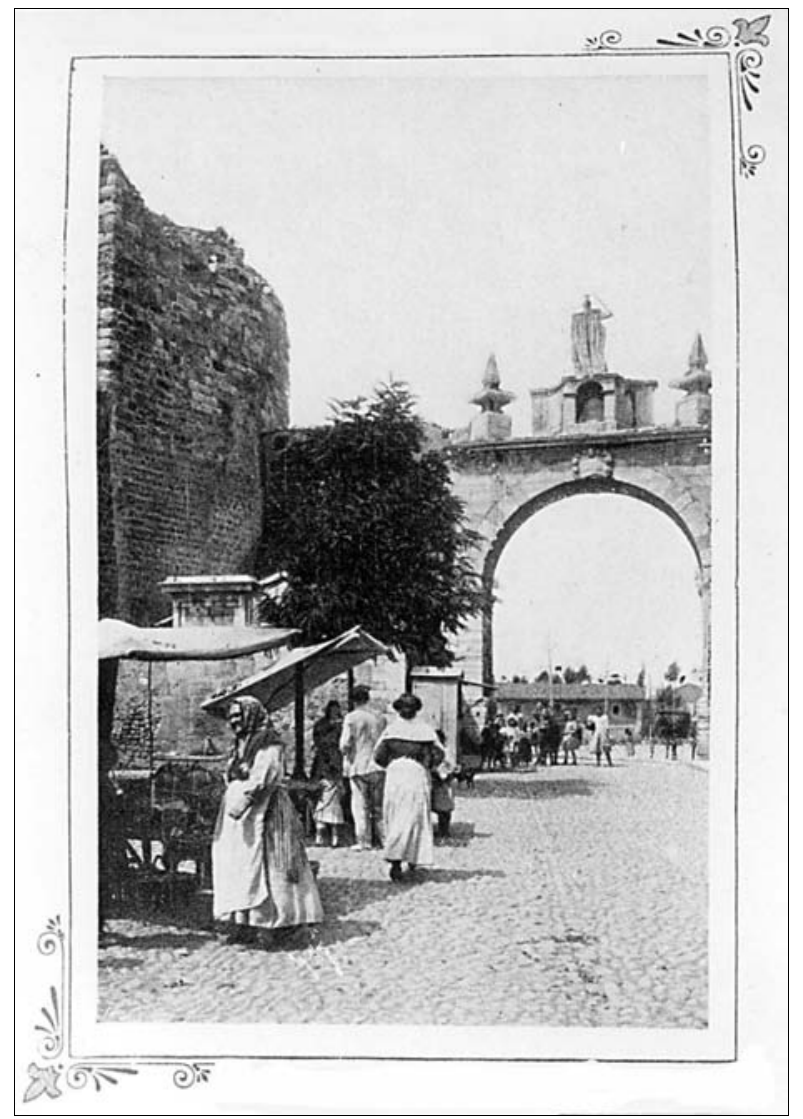

- Lám. 5. Puerta Castillo desde el interior. A la izquierda, el arca y la fuente de Carlos III

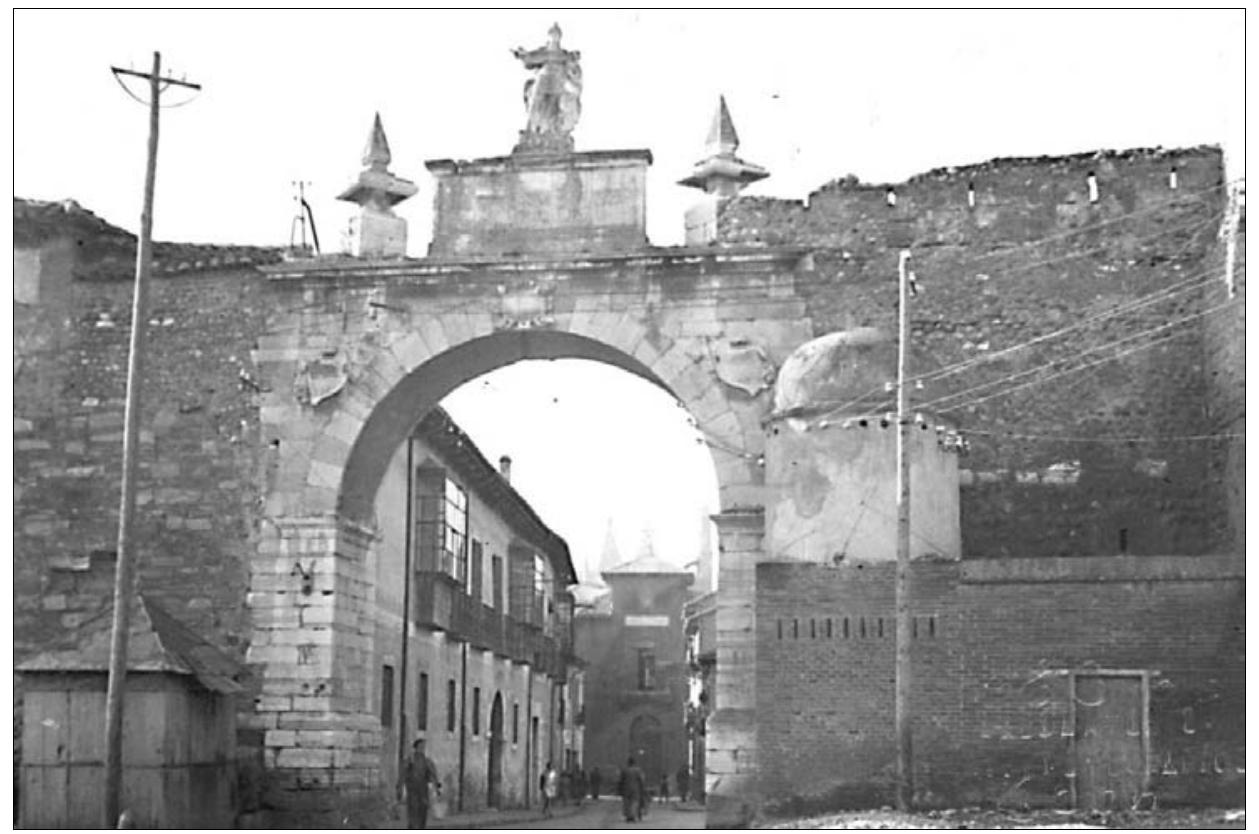

- Lám 6. Foto antigua de Puerta Castillo con diversas construcciones adosadas 


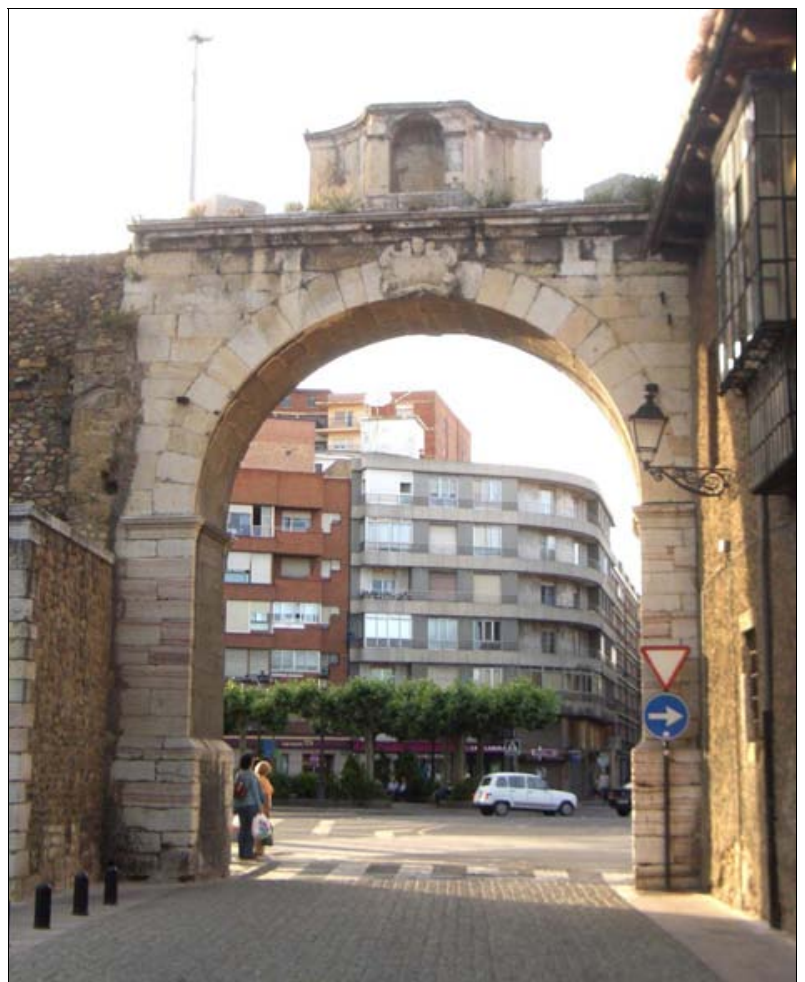

- Lám. 7. Puerta Castillo en la actualidad, desde el interior

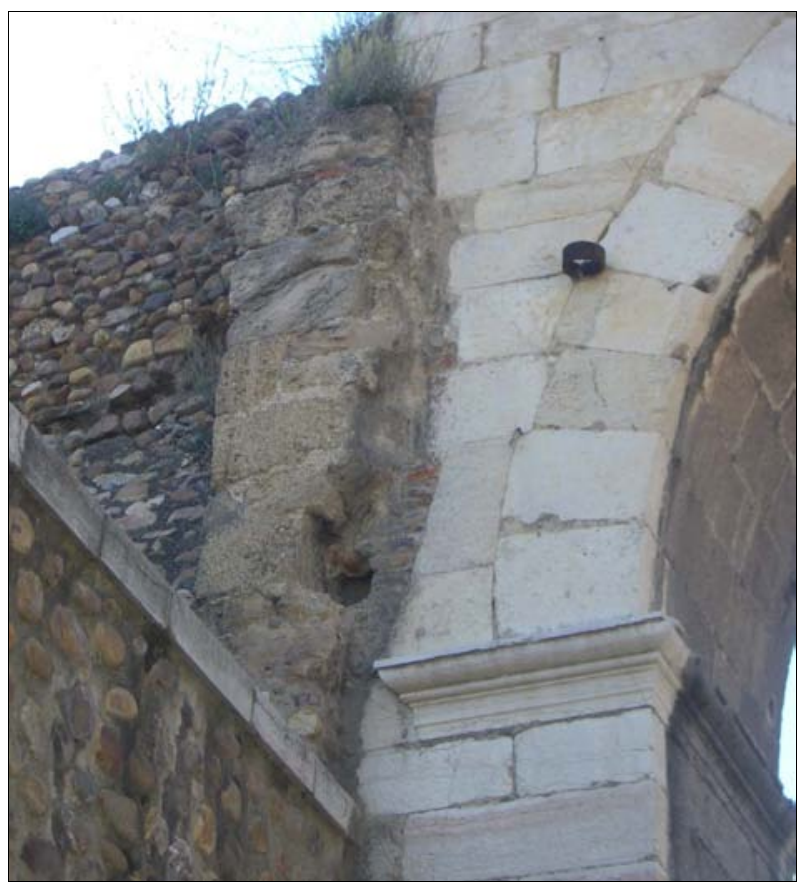

- Lám. 8. Detalle del pilar de sillares antiguos adosado a la estructura de la puerta 


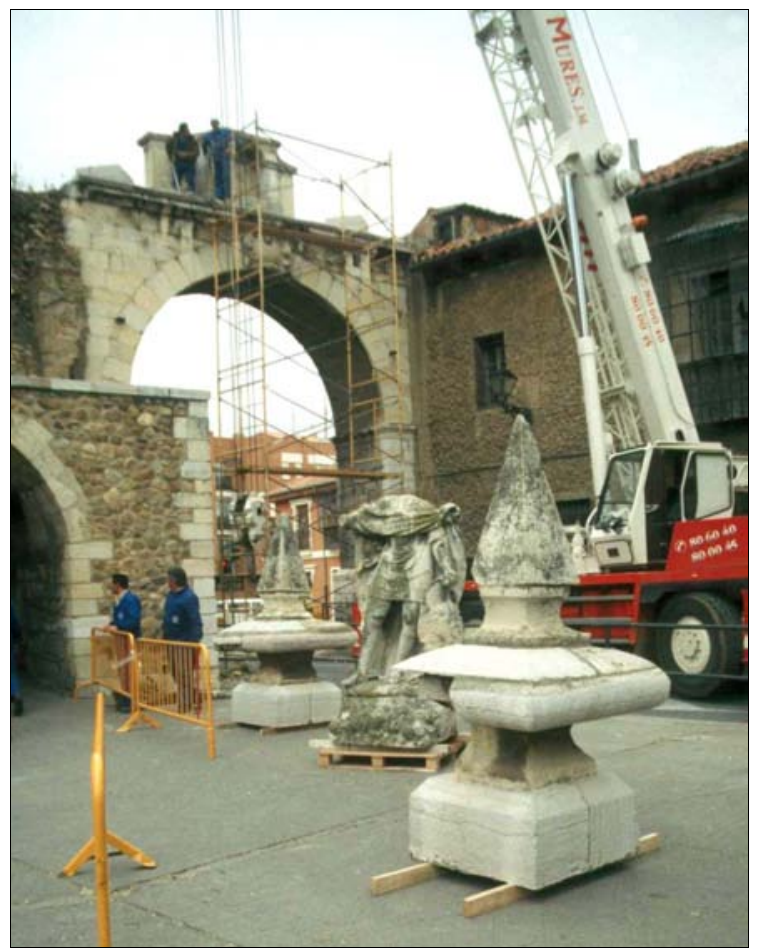

- Lám. 9. Desmontaje de la escultura y los adornos de Puerta Castillo

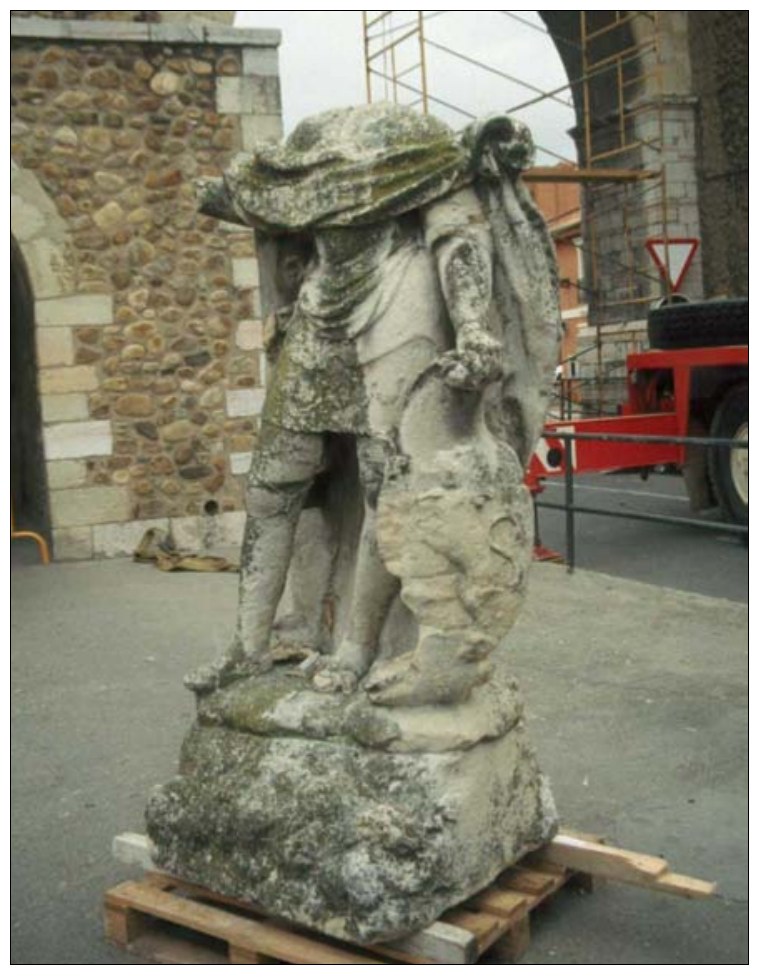

- Lám. 10. La escultura de Pelayo, descabezada y sin brazo 


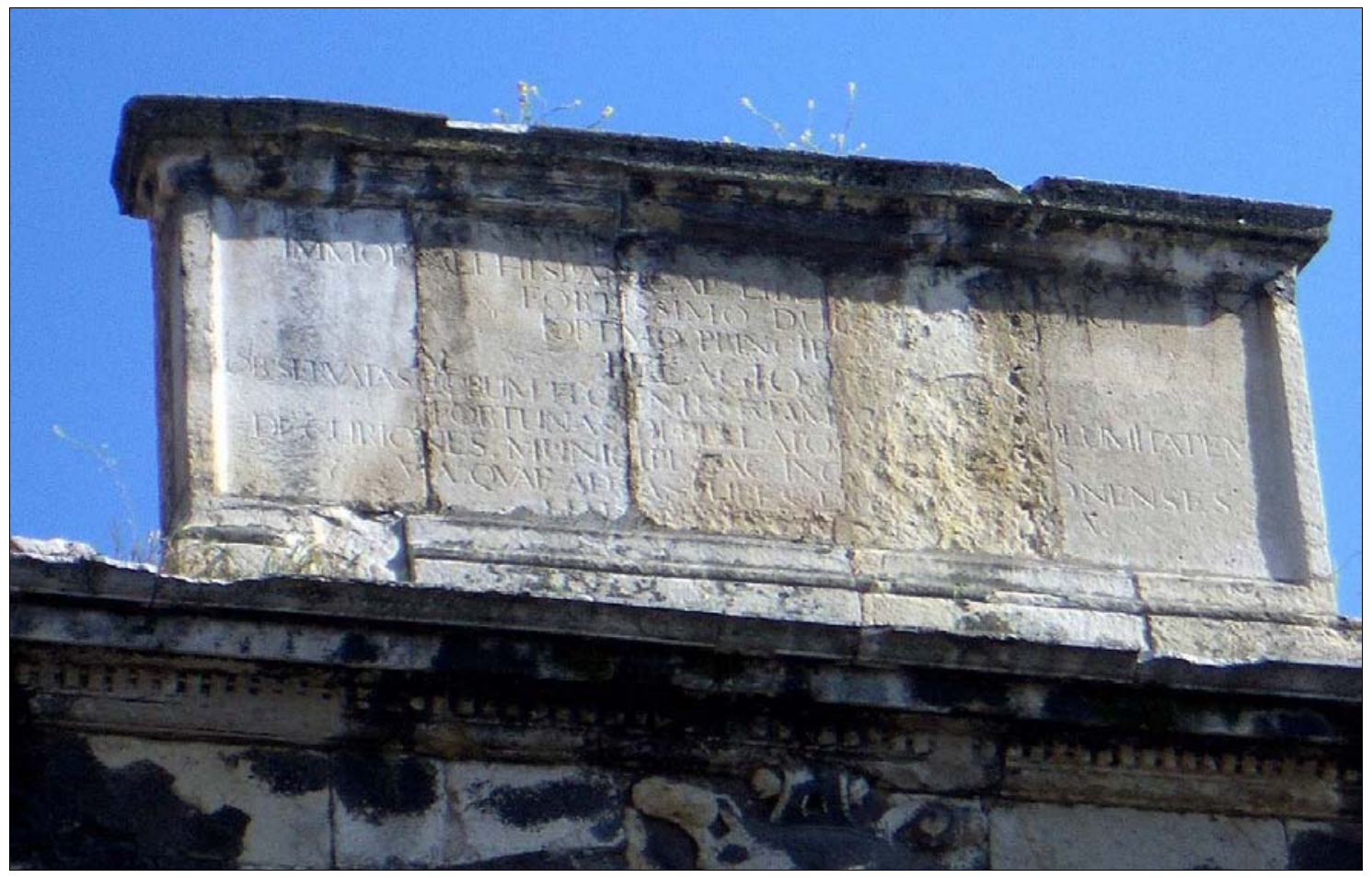

- Lám. 11. La inscripción del pedestal de Pelayo

VERAE CLARISSIMAEQUE GOTHORUM REGUM SOBOLI

INMORTALI HISPANICAE LIBERTATIS VINDICI

FORTISSIMO DUCI

OPTIMO PRINCIPE

PELAGIO

OBSERVATAS EORUM FLORENTISSIMAM URBEM INCOLUMITATEM

FORTUNAS DEBELLATOSQUE MAUROS

DECURIONES MUNICIPES AC INCOLAE LEGIONENSES

VIA QUAE AD ASTURES DUCIT STRATA

HAEC VOTA LITANT 1759 